\title{
Integration of logistic systems into regional transport services using road cargo transport
}

\author{
V. Cempírek*, A. Seidlová, J. Široký, P. Nachtigall, R. Kampf \\ Jan Perner Transport Faculty, University of Pardubice, Pardubice, Czech Republic \\ *Corresponding author: vaclav.cempirek@upce.cz
}

\begin{abstract}
The paper deals in the analytic part with problems of taxes and charges paid by users of road transport. Our team found that those payments are lower than for railroad transport, so that toll system implementation can't incite movement of transport from road to railroad. New partnerships between road and railroad companies can be set up here. This will lead to intermodal systems with savings on tolls, namely domestically, but in international transport. The proposal part of intermodal system deals with systems like Mobiler and Cargo Domino or Modalohr and Cargo Beamer. The conclusion is a better regional service technology and costs savings thanks to the cooperation of road and railroad transport. Intermodal systems are destined for a minimal hauling distance of $600 \mathrm{~km}$ with accompanied or unaccompanied transport.
\end{abstract}

KEY WORDS: Cargo system, logistic system, road, rail, transport.

\section{INTRODUCTION}

This paper sums up the partial results of the ongoing task „1F53A/126/520 Basic logistic systems applications in cargo transportation in defined regions and its optimal function".

In the year 2006 a partial goal in the proposed solution for logistic systems was supported by railroad transport in logistic chains and rationalization of technology in transport of LCL and FCL consignments in railway transport. Research objects by the end of the year 2007 have their goal in the establishment of an optimal number of formation yards and centers for the manipulation with LCL's.

Other partial goals (System rationalization of regional and national traffic network) were focused on finding reasons for decreasing the demand in railroad cargo transport and on other customer requirements. Basic logistic aspects related to the compact logistic chains have been found here. On this account a questionnaire has been formed. It has been filled by approximately 150 companies from the industry and business branches. From the questionnaire it follows that road transport is cheaper, more flexible and provides more logistic services than railroad transport does.

With regard to road-transport price an analysis of taxes and tolls has been made. The analysis dealt with taxes and tolls, which are paid by users of road transport and subsequently the impact of road-toll implementation on the competitive strength of road transport has been solved. Our results are that road transport is holding its strong position on transport market and it will be really hard to change it. Partially "The proposal of new intermodal road/railroad system" resolved find such system of service, which will fully accept 
cooperative relationships between two economic entities, each of them focused on different types of transport. We made a general analysis of the transport market in Switzerland, to find relevant answers for the general region-service using the road/railroad transport combination. The knowledge we got has been used for a summarization of recommendations for economical subjects in the Czech Republic.

\section{ANALYTIC PART}

From the statistical prognosis results the decreasing trend in railroad cargo-transport. The revitalization has to be consulted with experiences from West Europe, where it is usual that regional tracks are modernized only for passenger transport.

In the Czech Republic it is important, that manipulating tracks and handling areas for trucks have to remain after revitalization of regional tracks. If we ignore this rule, the intermodal systems, for example CargoDomino or Mobiler, can't be implemented. The part called "Proposal of new technology for regional services while using intermodal transport" follows. These problems will be solved in the year 2007, to find an optimal number of formation yards and centers for LCL consignments processing.

\section{THE LIBERALIZATION OF THE TRANSPORT MARKET}

From the submitted text it was seen that the liberalization of the transport market will bring much higher competitive pressures between different kinds of transport. Also the enforcement of cooperation between road and railroad transport is going to be very difficult, as the Swiss examples show. The Swiss federal rails AG, which have year by year problems with profitability, have another problem with the growth of competition in the railroad transport in the form of increasing number of private railway carriers.

Based on detailed analysis of Swiss rails we expect that it will be very hard for Czech Railways to realize transports of one-wagon and group-of-wagons transport of packages in the future.

Expected possible threats:

1. Cargo transport is on the second position (under passenger transport) from a timetablecreation point of view,

2. Whole-network tact-timetable influences train-forming plans in cargo transport, so that the demand time table is transiting to supply time table.

3. The biggest weakness of national railroad cargo transport system is that it has never been orientated to general area servicing,

4. Capacity is also induced by the homogeneity of each train on certain track. Nowadays the speed of fast trains, Eurocity trains or Intercity trains is rather comparable with transit goods-trains,

5. For general area service of customers without a direct railroad-connection the CargoDomino system is advantageous, which is unpretentious on system technology or technical road/railroad container reloading equipment,

6. The positive progression of railroad transport can be supported by strict legislation, which will restrict road transport via strictly abiding with the rules of traffic operations or self and social rulings. 


\section{THE SERVICE OF THE REGIONAL AND NATIONAL TRANSPORTATION NETWORK AND ITS RATIONALIZATION}

In this section, an analysis of taxes and tolls paid by users of road transport has been done. The conclusion was that road-users pay less than railroad-users do. In the connected toll accounting proposal the idea is presented that the toll implementation will not decrease the competitive strength of road transport. Here will be a space for co-operative relationships between road and railroad haulers (using intermodal transport), which will lead to costsavings in the case of tolls.

One part of the solution is in the intermodal system for the operation of an engaged area called Mobiler or CargoDomino (national transports) and Modalohr or CargoBeamer (international transports). All systems are described in detail with the advantages and disadvantages of each system. The solution is attached with pictures in the enclosure. This section is followed by the technology of area service via intermodal transport and here high possible savings in co-operation were found, due to the nonpayment of tolls. Intermodal systems are profitable from $600 \mathrm{~km}$ for accompanied or unaccompanied transport. This year a detailed analysis of railroad transport in Switzerland was completed and the results from this are in implementation for our conditions.

\section{TECHNOLOGY OF AREA SERVICE VIA INTERMODAL TRANSPORT}

The proposal of transport system logistic applications, which uses a combination of road and railroad transport, can be applied on a wall-to-wall service of the area including a proposal of haulage intermodal units.

Nowadays a few types of verified systems are under operation with a documented positive impact on modal split, economic effects and the discharge of road infrastructure.

Such systems include Mobiler, Cargo Domino, Modalohr and eventually CargoBeamer.

From figure 1 it can be seen how such a service can be realized via different types of trains. On the picture with red arrows is an illustrated service of stations on regional tracks or eventually way stations via slow goods trains. Those trains will carry cargo to railway centers.

In the railway centers the cargo will be switched to continuous trains (green arrows) and the cargo will be transferred to the formation yard. Here "higher quality" cargo trains will be formed according to final destination (blue arrows).

The above mentioned, and described in the project, intermodal systems are modest regarding technical equipment for the manipulation of intermodal units.

In all cases it is horizontal reload. By the system Mobiler and Cargo Domino the reload can be realized near the manipulating track on hard surfaces. Road cargo carrier rides longways to the manipulating track with as much minimal distance as between loading areas for a smooth reload. A prerequisite is maximal vertical tolerance between the loading areas $\pm 15 \mathrm{~cm}$.

Premises for the utility of the system:

1. A sufficient number of cargo wagons,

2. Availability of wagons,

3. Suitable informative and control system,

4. Electronic carriage document,

5. Service of railway station by slow goods trains twice a days,

6. Implementation of system "Night jump",

7. Minimal demand on manpower. 


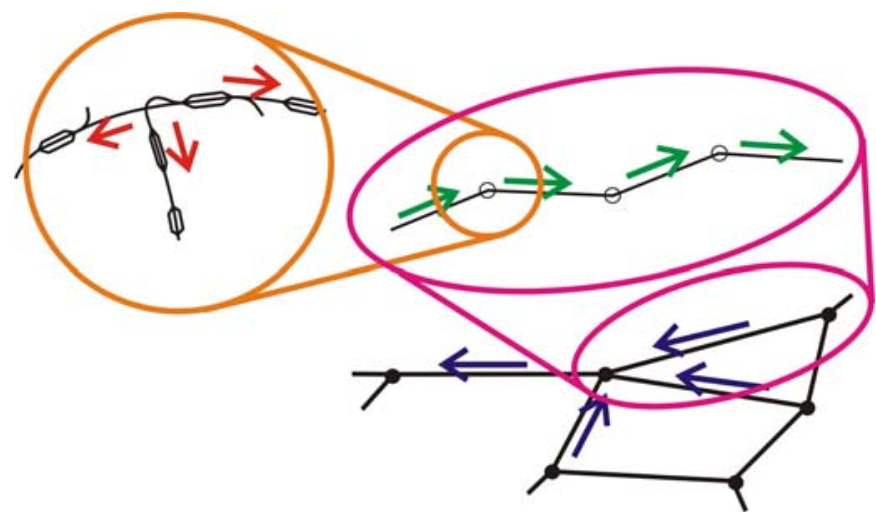

Figure 1: Schema of wall-to-wall area service via railroad transport

Source: Authors

\section{ECONOMIC EFFECTS ARISING FROM CHANGES IN MEAN OF TRANSPORT FROM ROAD TO RAILROAD}

a) Direct road transport

Figure 2 represents the organization of direct road transport with two possible scenarios. In the first one, goods carrier serve at the place A customers A1 to An (consigner) and after traveling 600 and more $\mathrm{km}$ will serve target customers (receivers) B1 to Bn.

In the second scenario smaller goods carriers ( $<12$ tons) will serve at the place A service of customers A1 to An (consigners) via a circular journey and gives the package to a logistic centre. In the logistic centre the packages will be consolidated according to directions and the cargo carrier $(>12 \mathrm{t}$ ) will transport them to logistic centre in the area B and in the area B those packages are redistributed via a circular journey to target customers (receivers) B1 to $\mathrm{Bn}$.

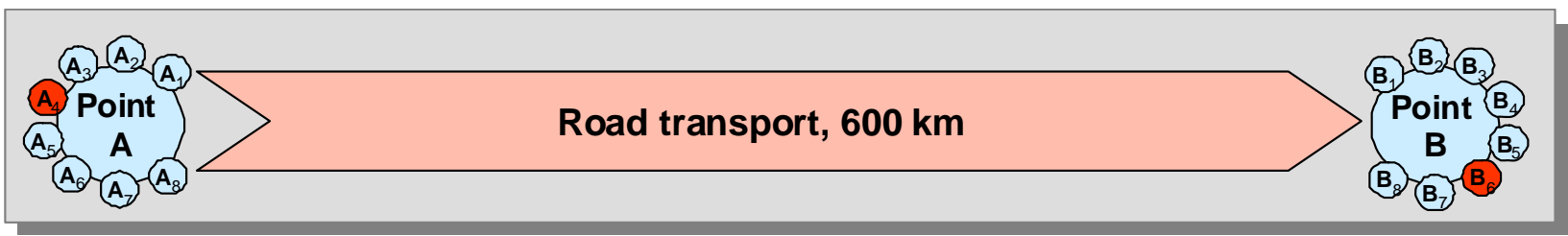

Source: Authors

Figure 2: Direct road transport

Disadvantages of this system:

- low speed of transport,

- separation of the drive from the family,

- toll payment,

- attrition of infrastructure, congestions, accidents and so on.

b) Combined transport road/railroad

Figure 3 shows the organization of intermodal transport with the haulage of packages via road transport and their transport between areas A and B is supported by railroad transport. The combination of these means of transport derives benefit from both means of transport. 


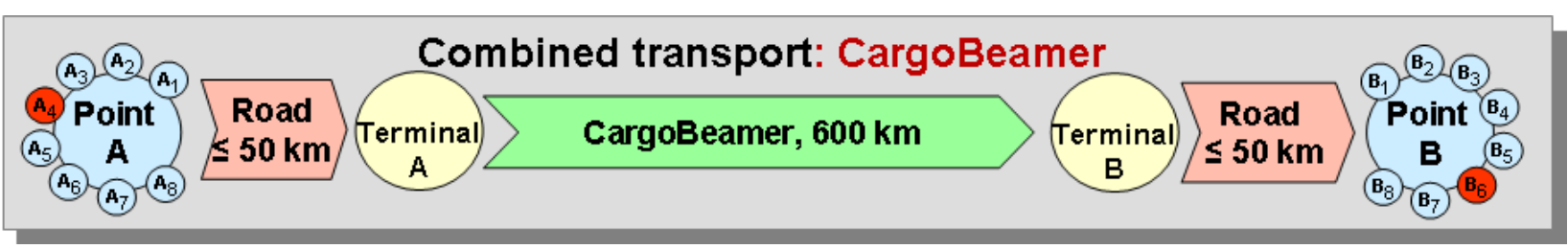

Figure 3: Combined transport road/railroad

Source: Authors

Advantages of this system:

- relieves the road infrastructure,

- no payment for toll,

- better labour conditions for drivers,

- lower carriage charges,

- lower production of pollutants.

If a higher cooperation between road and railroad transport will be seen high savings on toll can be achieved. From the shown schemes large savings can be evaluated. On the forwarding distance $600 \mathrm{~km}$ there will be savings of $4.20 \mathrm{Kc \check {c }} / \mathrm{km}$ (for trucks with engines EURO III and 4 and more axles) which makes 2520 Kč for one journey.

\section{THE POSSIBILITIES OF A MORE EXTENSIVE USE OF RAILROAD TRANSPORT}

During the solving of this problem, we made a list of investigations by approximately 150 companies from industry branches and from business sectors. The lists of investigations that were sent back by e-mail were over $20 \%$ of the total.

The target of the list of investigations was on usually used means of transport and on required logistic services. The results are clear: $86 \%$ of companies use road transport and only $9 \%$ railroad transport. The answers nearly correlate with the statistics yearbook; each year the share of railroad transport is smaller and smaller compared to road transport.

Nearly $73 \%$ of companies solve questions about means of transport and only $27 \%$ leave it to a forwarder. If we can achieve a change in that share, the situation will be much more positive for mass types of transport, like railroad transport.

If we exclude the clear influences leading to a change from road to railroad transport, like rises in the price of fuel, tolls or bottlenecks on the infrastructure with hypo-permeability (rise of congestions), than nearly $43 \%$ of companies are unsatisfied with railroad service offers.

From the answers in the section targeted on road transport it was seen that only $20 \%$ of companies realize their transport with their own vehicles. This is not surprising with regard to the high number of licenses for prosecution of road transport in Czech Republic. We also asked for additional services offered by external haulers and the highest interest was in the following services: compounding of packages $13 \%$, manipulation (loading and unloading) $19 \%$, distribution organization $13 \%$ and delivery on agreed time $24 \%$. Other services are nearly equal with no more than $10 \%$. Highest requirements are on delivery Just in Time and Just in Time Sequence, because interviewed companies are connected to the supply chains for the automobile and the electro-technical industries. Road transport is used for international transports by $42 \%$ and for intrastate by $58 \%$. 'We can agree with these values, because intrastate transport support also transports ovenware and raw materials. Road cargo transport offers many advantages to their users, such as: higher speed $22 \%$, flexibility $16 \%$, door-todoor transport $14 \%$, price $11 \%$, availability $8 \%$ and just in time supply $8 \%$. It's possible that if we will ask for a smaller number of decisive priorities, then the percentage volumes will be different (higher). The flexibility of road cargo transport is incomparable for other means of transport. Therefore road transport will always be part of logistic chains. 
In the railway transport is $100 \%$ of transports realized by external haulers. We can assume that it was in $100 \% \check{C}$, a.s. Polled customers said, that they take an interest in additional services from external haulers on the related logistic centers. Namely for JIT $22 \%$, consolidation of packages $10 \%$, manipulations $17 \%$ (loading, unloading, reloading) and stocking $10 \%$. Other services had less than $10 \%$. From the answers it is clear that we have to support the development of logistic centers with a minimum of two means of transport and a wide spectrum of services.

Railroad transport also offers other advantages like: manipulation $17 \%$, price $32 \%$, lower costs per transported ton $17 \%$, high-capacity wagons $17 \%$, transport of dangerous articles $17 \%$. High-capacity wagons have nearly a double higher capacity than road cargo vehicles. That fact is followed by lower price for transported ton.

Statistical prognosis shows a decreasing trend in railroad cargo transport in West Europe. In West Europe regional tracks are revitalized only for passenger transport. In contrast, in the Czech Republic we must keep manipulating tracks and hard surfaces at the stations on regional track for the development of intermodal systems. We can't implement systems like CargoDomino, Mobiler and so on, if we don't keep the above mentioned terms

\section{CONCLUSION}

This paper deals, in the analytical section, with the problems of tolls and charges which are paid by users of road transport and the conclusion is that the charges are smaller than in railroad transport. The authors think that the toll for using road routes will not decrease the competitive strength of road transport to the benefit of railroad transport. There is a possibility to establish a cooperative relationship between road - railroad transport.

The proposed intermodal road/railroad system gives a wall-to-wall service of regions via Mobiler or Cargo Domino and for international transport and proposed two systems (Modalohr or CargoBeamer). In conclusion the partial output is focused on area service technology using intermodal transport road/railroad and authors point out that the intermodal system is profitable for a minimum distance $600 \mathrm{~km}$ for both types of transport (accompanied or unaccompanied).

\section{REFERENCES}

Cempírek, V. a kol. Zpráva projektu "Návrhy základních aplikaci logistických systémů do nákladní obslužné prepravy stanovených regionů a zajištění jeji optimální funkčnosti“, Pardubice, 31. 1. 2007.

Cempírek, V., Široký, J., Nachtigall, P. Development of intermodal transport in Central and Eastern Europe, WorldCargo News 5/2006, s. 55-56, ISSN 1355-0551.

Cempírek, V., Široký, J., Nachtigall, P. New prospects for intermodal transport, WorldCargo News 11/2006, s. 26, ISSN 1355-0551.

The presented results are part of the task VLC2005CDVUP announced by the Ministry of Transport "Concept of public logistic centres in the Czech Republic in context of the importance of strengthening multimodal freight transport" with the solving period 2005-2008. 